\title{
Soil-atmosphere exchange of carbonyl sulfide in a Mediterranean citrus orchard
}

\author{
Fulin Yang ${ }^{1,2}$, Rafat Qubaja ${ }^{1}$, Fyodor Tatarinov ${ }^{1}$, Rafael Stern $^{1}$, and Dan Yakir ${ }^{1}$ \\ ${ }^{1}$ Earth and Planetary Sciences, Weizmann Institute of Science, Rehovot 76100, Israel \\ ${ }^{2}$ College of Animal Sciences, Fujian Agriculture and Forestry University, Fuzhou 350002, China \\ Correspondence: Dan Yakir (dan.yakir@weizmann.ac.il)
}

Received: 16 November 2018 - Discussion started: 3 December 2018

Revised: 27 February 2019 - Accepted: 11 March 2019 - Published: 25 March 2019

\begin{abstract}
Carbonyl sulfide (COS) is used as a tracer of $\mathrm{CO}_{2}$ exchange at the ecosystem and larger scales. The robustness of this approach depends on knowledge of the soil contribution to the ecosystem fluxes, which is uncertain at present. We assessed the spatial and temporal variations in soil $\mathrm{COS}$ and $\mathrm{CO}_{2}$ fluxes in a Mediterranean citrus orchard combining surface flux chambers and soil concentration gradients. The spatial heterogeneity in soil COS exchange indicated net uptake below and between trees of up to $4.6 \mathrm{pmol} \mathrm{m}^{-2} \mathrm{~s}^{-1}$ and net emission in sun-exposed soil between rows of up to $2.6 \mathrm{pmol} \mathrm{m}^{-2} \mathrm{~s}^{-1}$, with an overall mean uptake value of $1.1 \pm 0.1 \mathrm{pmol} \mathrm{m}^{-2} \mathrm{~s}^{-1}$. Soil COS concentrations decreased with soil depth from atmospheric levels of $\sim 450$ to $\sim 100 \mathrm{ppt}$ at $20 \mathrm{~cm}$ depth, while $\mathrm{CO}_{2}$ concentrations increased from $\sim 400$ to $\sim 5000 \mathrm{ppm}$. COS flux estimates from the soil concentration gradients were, on average, $-1.0 \pm 0.3 \mathrm{pmol} \mathrm{m}^{-2} \mathrm{~s}^{-1}$, consistent with the chamber measurements. A soil COS flux algorithm driven by soil moisture and temperature $(5 \mathrm{~cm}$ depth) and distance from the nearest tree, could explain $75 \%$ of variance in soil COS flux. Soil relative uptake, the normalized ratio of $\operatorname{COS}$ to $\mathrm{CO}_{2}$ fluxes was, on average, $-0.4 \pm 0.3$ and showed a general exponential response to soil temperature. The results indicated that soil COS fluxes at our study site were dominated by uptake, with relatively small net fluxes compared to both soil respiration and reported canopy COS fluxes. Such a result should facilitate the application of COS as a powerful tracer of ecosystem $\mathrm{CO}_{2}$ exchange.
\end{abstract}

\section{Introduction}

Carbonyl sulfide (COS) is a sulfur-containing analogue of $\mathrm{CO}_{2}$ that is taken up by vegetation following a similar pathway to $\mathrm{CO}_{2}$, ultimately hydrolyzed in an irreversible reaction with carbonic anhydrase. It therefore holds great promise for studies of photosynthetic $\mathrm{CO}_{2}$ uptake (Asaf et al., 2013; Berry et al., 2013; Wehr et al., 2017; Whelan et al., 2018). One of the difficulties in the application of COS as a tracer for photosynthetic $\mathrm{CO}_{2}$ uptake is that the non-leaf contributions to the net ecosystem COS flux are poorly characterized. There are reports of substantial soil fluxes, indicating both uptake and emissions (Kesselmeier et al., 1999; Kuhn et al., 1999; Masaki et al., 2016; Seibt et al., 2006; Yang et al., 2018; Yi et al., 2007). Although soil COS exchanges were in some cases small compared to plant uptake (e.g., Yang et al., 2018; Berkelhammer et al., 2014), this was not always the case. Substantial soil COS emissions have been found in wetlands and anoxic soils (Li et al., 2006; Whelan et al., 2013) and in senescing agricultural fields and high temperatures (Liu et al., 2010; Maseyk et al., 2014) or under drought conditions and in response to UV radiation (Kitz et al., 2017). Even for the same soil, COS fluxes could show large variations and both uptake and emission with sensitivities to soil moisture and ambient COS concentrations (Bunk et al., 2017; Kaisermann et al., 2018). These studies also assessed the response of COS exchange to environmental controls, e.g., soil moisture and temperature and solar radiation.

For COS application as a tracer of ecosystem $\mathrm{CO}_{2}$ exchange, characterizing the relationships between $\operatorname{COS}$ and $\mathrm{CO}_{2}$ fluxes is important. This is done by assessing the "relative uptake" (RU) of the $\mathrm{COS} / \mathrm{CO}_{2}$ flux rate ratio, normalized by the ambient atmospheric concentrations (that differ 
for the two gases by a factor of about $10^{6}$ ), as done at the leaf scale (LRU) or ecosystem scale (ERU; e.g., Asaf et al., 2013). It was similarly applied to soil as SRU (Berkelhammer et al., 2014). Conservative, or predictable, SRU values reflect systematic relationships between the processes influencing $\mathrm{CO}_{2}$ and $\mathrm{COS}$, and they could help the identification of the dominant process and support the application of COS as tracer. Small SRU values compared to LRU could also indicate a reduced effect of soil on ecosystem fluxes. For example, Berkelhammer et al. (2014) reported a mean SRU of -0.76 , which is about half of the leaf value of about +1.7 , indicating that compared to $\mathrm{CO}_{2}$, leaf $\mathrm{COS}$ is enhanced and soil COS uptake is suppressed, which provides additional robustness to the COS-GPP (where GPP is gross primary productivity) approach. Note also that soil $\mathrm{CO}_{2}$ flux measurements and modeling are much more common than for COS at flux sites. Knowledge of SRU could help derive soil COS fluxes and, for example, improve the partitioning of canopy

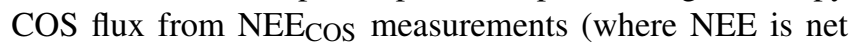
ecosystem exchange).

Soil COS exchange has often been measured by incubations in the lab (e.g., Bunk et al., 2017; Kesselmeier et al., 1999; Liu et al., 2010; Van Diest and Kesselmeier, 2008), by static or dynamic chambers in the field (e.g., Berkelhammer et al., 2014; Kitz et al., 2017; Sun et al., 2018; Yi et al., 2007; Mseyk et al., 2014) and using models (e.g., Ogée et al., 2016; Sun et al., 2015; Whelan et al., 2016). In spite of these efforts, more field measurements of soil COS exchange are clearly needed as a basis for elucidating underlying mechanisms, as well as obtaining a better quantitative record of the possible range of soil COS fluxes under natural conditions. Note also that previous studies have focused on agricultural soils (Maseyk et al., 2014), wetlands (Whelan et al., 2013), boreal forest soils (Sun et al., 2018) and grasslands (Kitz et al., 2017), but several ecosystems are understudied, such as in those the Mediterranean. Finally, soil profile measurements will also be useful for the validation of soil models of COS exchange (Sun et al., 2015). The objective of this study was to apply dynamic chambers measurements, constrained by simultaneous soil gradient method, to assess the spatial and temporal variations in soil $\mathrm{COS}$ and $\mathrm{CO}_{2}$ fluxes in a citrus orchard ecosystem where contrasting soil micro-site conditions occur.

\section{Materials and methods}

\subsection{Field site}

The study was conducted in an orchard in Rehovot, Israel ( $31^{\circ} 54^{\prime} \mathrm{N}, 34^{\circ} 49^{\prime} \mathrm{E}$; $50 \mathrm{~m}$ a.s.1.), in 2015 and 2016. The orchard is a plantation of lemon trees (Citrus limonia Osbeck), with $5 \mathrm{~m}$ distance between rows and $4 \mathrm{~m}$ between trees. Mean annual air temperature at the site is $19.7^{\circ} \mathrm{C}$, and mean annual precipitation is $537 \mathrm{~mm}$. Most of the precipitation $(82 \%)$ falls in November to February, with no rain during June to October. A trickle irrigation system was used from May to September with the standard irrigation plan of the orchard management. The soil in the area is brown red sandy soil (hamra soil) with an average bulk density of $1.6 \mathrm{~kg} \mathrm{~m}^{-3}$ and a pH of 6.5 (Singer, 2007). Although root distribution was not measured, we noted that roots were concentrated mainly within about $50 \mathrm{~cm}$ of the tree trunks, as could be expected due to drip irrigation installed around the trunk.

\subsection{Quantum cascade laser measurements}

We used the commercially available quantum cascade laser (QCL) system (Aerodyne Research, Billerica, MA) with a tunable laser absorption spectrometer (model: QC-TILDAS$\mathrm{CS}$ ) to measure $\mathrm{COS}, \mathrm{CO}_{2}$ and water vapor concentrations simultaneously. The device was installed in a mobile lab, described by Asaf et al. (2013). COS is detected at $2050.40 \mathrm{~cm}^{-1}$ and $\mathrm{CO}_{2}$ at $2050.57 \mathrm{~cm}^{-1}$ at a rate of $1 \mathrm{~Hz}$. The instrument was calibrated using a working reference compressed air tank that was used for intercomparison with the NOAA GMD lab (Boulder CO). Corrections for water vapor were made using the TDLWINTEL software installed in the QCL (Kooijmans et al., 2016).

\subsection{Soil chamber flux measurements}

A custom-made stainless-steel cylindrical chamber of $177 \mathrm{~cm}^{2}$ directly inserted into the soil $(\sim 5 \mathrm{~cm})$ was used, as previously described (Berkelhammer et al., 2014; Yang et al., 2018). The chambers were opaque, and photoproduction was not considered in this study. The chamber air and ambient air flows were pumped to the QCL analyzer through two 3/8 inch diameter Decabon tubing. The flow rate was maintained at $1.2 \mathrm{~L} \mathrm{~min}^{-1}$ and repeatedly cycled with a $1 \mathrm{~min}$ instrument background (using $\mathrm{N}_{2}$ zero gas), 9 min ambient air flow and 10 min chamber air sample. Three different soil sites were used with distance of 3.20, 2.00 and $0.25 \mathrm{~m}$ away from a tree trunk, which represented sampling sites between rows (BR), between trees (BT) and under tree (UT). Each sampling site was measured continuously for $24 \mathrm{~h}$ and cycled between sites for the duration of the campaign. Four measurement campaigns were carried out during 5-9 August and 25-28 December 2015 and 5-9 May and 28-31 July 2016.

Gas exchange rates, $F_{c}$, were calculated according to

$F_{c}=\frac{Q}{A} \times\left(\Delta C_{\text {sample }}-\Delta C_{\text {blank }}\right)$,

where $Q$ is the chamber flush rate in $\operatorname{mols}^{-1}, A$ is the enclosed soil surface in $\mathrm{m}^{2}$, and $\Delta C$ is the gas concentrations difference between chamber air and ambient air in pmol mol${ }^{-1}$ for COS and $\mu \mathrm{mol} \mathrm{mol}^{-1}$ for $\mathrm{CO}_{2}$ under sampling and blank reference treatments (using the same chamber placed above a sheet of aluminum foil before and after measurement at each site). Hereafter, the soil fluxes are reported in pmol m $\mathrm{m}^{-2} \mathrm{~s}^{-1}$ and $\mu \mathrm{mol} \mathrm{m} \mathrm{m}^{-2} \mathrm{~s}^{-1}$ for $\mathrm{COS}$ and $\mathrm{CO}_{2}$, 
respectively. SRU is used to characterize the relationship between soil $\mathrm{CO}_{2}$ and $\mathrm{COS}$ fluxes and was estimated from the normalized ratio of $\mathrm{CO}_{2}$ respiration to $\mathrm{COS}$ uptake (negative values) or emission (positive values) fluxes (Berkelhammer et al., 2014):

$\mathrm{SRU}=\frac{F_{\mathrm{COS}_{\text {soil }}}}{[\mathrm{COS}]} / \frac{F_{\mathrm{CO}_{2 \text { soil }}}}{\left[\mathrm{CO}_{2}\right]}$.

\subsection{Soil concentration profile measurements}

Four campaigns of soil concentration profile measurements were carried out during 1-2 March, 20-26 April, 10 May and 22-28 June 2016. The trace gas at five soil depths of $0,2.5,5.0,10$ and $20 \mathrm{~cm}$ was sampled at each of the three micro-sites: BR, BT and UT.

Four individual Decabon tubes were inserted at adjacent but different points into the soil (to avoid communication between tubes during sampling) to the different depths indicated above and connected directly to the QCL positioned close by the mobile lab. At least 1 day after insertion and ensuring sealing between tubing and soil, soil air was sampled with flow rate of $80 \mathrm{~mL} \mathrm{~min}^{-1}$ in a $10 \mathrm{~min}$ cycle of $1 \mathrm{~min}$ instrument background, 3 min surface air (depth 0 ; used initially to flush all aboveground tubing), $5 \mathrm{~min}$ sampling of a depth point in the profile (first 2 min for flushing the tubing, third minute used for data; up to $400 \mathrm{~mL}$ extracted from the soil) and finally $1 \mathrm{~min}$ surface air. Five complete sets of cycles including the four soil depths and surface air were repeated for each site (with time gaps between cycles of hours and in some cases overnight). The pressure in the $500 \mathrm{~mL}$ QCL sample cell was kept at 15 Torr to ensure sufficient turnovers $\left(\sim 8 \mathrm{~min}^{-1}\right.$ using the low flow rate) before data were recorded.

Assuming that at the selected measurement sites, soil trace gas is only transported by diffusion, soil $\mathrm{COS}$ and $\mathrm{CO}_{2}$ fluxes were estimated based on Fick's first law:

$F=-D_{\mathrm{s}} \frac{\mathrm{d} C}{\mathrm{~d} z_{\text {soil }}}$,

where $F$ is the upward or downward gas flux $\left(\mathrm{pmol} \mathrm{m}^{-2} \mathrm{~s}^{-1}\right.$ for $\mathrm{COS}$ and $\mu \mathrm{mol} \mathrm{m}{ }^{-2} \mathrm{~s}^{-1}$ for $\mathrm{CO}_{2}$ ), $D_{\mathrm{s}}$ is the effective gas diffusion coefficient of the relevant gas species in the soil $\left(\mathrm{m}^{2} \mathrm{~s}^{-1}\right), C$ is the trace gas concentration (mixing ratio, converted from the measured mole fractions) and $z_{\text {soil }}$ is the soil depth (m).

The Penman (1940) function was used to describe the soil diffusion coefficient $\left(D_{\mathrm{s}}\right)$ as in Kapiluto et al. (2007):

$D_{\mathrm{s}}=D_{\mathrm{a}}\left(\theta_{\mathrm{s}}-\theta\right) \sqrt{\frac{T_{\mathrm{s}}+273.15}{298.15}}$,

where $\theta_{\mathrm{s}}$ is the soil saturation water content and $\theta$ is the measured soil volumetric water content. $D_{\mathrm{a}}$ is the trace gas diffusion coefficient in free air, which varied with temperature and pressure, given by

$D_{\mathrm{a}}=D_{\mathrm{a} 0}\left(\frac{T_{\mathrm{s}}+273.15}{293.15}\right)^{1.75}\left(\frac{P}{101.3}\right)$,

where $D_{\mathrm{a} 0}$ is a reference value of the trace gas diffusion coefficient at $293.15 \mathrm{~K}$ and $101.3 \mathrm{kPa}$, given as $1.24 \times$ $10^{-5} \mathrm{~m}^{-2} \mathrm{~s}^{-1}$ for COS (Seibt et al., 2010) and $1.47 \times$ $10^{-5} \mathrm{~m}^{-2} \mathrm{~s}^{-1}$ for $\mathrm{CO}_{2}$ (Jones, 2013); $T_{\mathrm{S}}$ is soil temperature $\left({ }^{\circ} \mathrm{C}\right)$, and $P$ is air pressure $(\mathrm{kPa})$.

\section{Results}

\subsection{Variations in soil COS flux}

Soil COS fluxes showed significant heterogeneity at both the spatial (micro-sites) and temporal (seasonal) scale (Fig. 1). Overall, the hourly soil COS flux varied from -4.6 to $+2.6 \mathrm{pmol} \mathrm{m}^{-2} \mathrm{~s}^{-1}$, with a mean value of $1.1 \pm$ $0.1 \mathrm{pmol} \mathrm{m}^{-2} \mathrm{~s}^{-1}$. On the spatial scale, the COS fluxes showed systematic uptake UT, moderate uptake and some emissions BT, and relatively more emission in the exposed area $\mathrm{BR}$, with diurnal mean values across seasons of $-3.0 \pm$ $0.1,-0.4 \pm 0.14$ and $+0.1 \pm 0.1$ pmol m$^{-2} \mathrm{~s}^{-1}$, respectively.

On the diurnal timescale, soil COS flux were generally higher in the afternoon (peaking around 15:00-16:00), declining at night and in the early morning (Fig. 1). On the seasonal timescale, soil COS fluxes showed both changes in rates and shifts from net uptake to net emission, with the site hierarchy differing in the different seasons (Fig. 1). At the UT site where only COS uptake was observed, the highest rates were observed in winter and peak summer (December and August) with diurnal mean rates of nearly -4 pmol m$^{-2} \mathrm{~s}^{-1}$ and more moderate uptake rates of around $-2 \mathrm{pmol} \mathrm{m}^{-2} \mathrm{~s}^{-1}$ in spring and early summer (May and July; Fig. 1). At the BT sites, significant COS uptake of $\sim-2.5 \mathrm{pmol} \mathrm{m}^{-2} \mathrm{~s}^{-1}$ was observed in winter, but net fluxes were near zero at other times, with some afternoon emission in summer. At the exposed BR sites, minor uptake (less than $-1 \mathrm{pmol} \mathrm{m}^{-2} \mathrm{~s}^{-1}$ ) was observed in spring and early summer, but there was consistent emission in peak summer, with diurnal mean values of nearly $+2 \mathrm{pmol} \mathrm{m}^{-2} \mathrm{~s}^{-1}$.

\subsection{Effects of moisture and temperature}

During the hot summer (August 2015 and July 2016), differences in micro-site soil water content $(\theta)$ were most distinct, with $\theta$ of nearly $30 \%$ at the UT sites (associated with drip irrigation) but of $\sim 19 \%$ and $\sim 12 \%$ at the BT and BR sites. Correspondingly, the UT sites had significant COS uptake of about -3 pmol $\mathrm{m}^{-2} \mathrm{~s}^{-1}$, while the other sites showed emission of about $+1 \mathrm{pmol} \mathrm{m}^{-2} \mathrm{~s}^{-1}$ (Table 1). In winter (December), $\theta$ at the three sites was similar $(\sim 25 \%)$, and all sites showed soil COS uptake, but with clear gradients of -3.9 , -2.5 and $-0.7 \mathrm{pmol} \mathrm{m}^{-2} \mathrm{~s}^{-1}$ at the UT, BT and BR sites, 

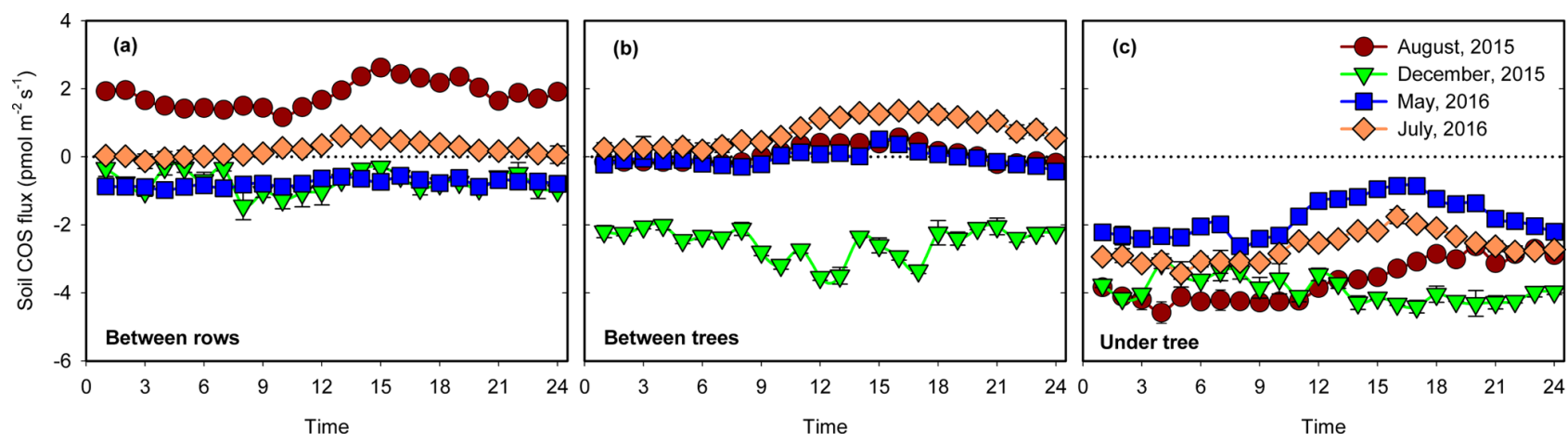

Figure 1. Spatial variability of soil COS flux at three sites: between trees (a), between rows (b) and under tree (c). Each panel shows the diurnal cycling of soil COS flux in the four campaigns. Each data point was the hourly mean $\pm 1 \operatorname{SE}(N=3)$.

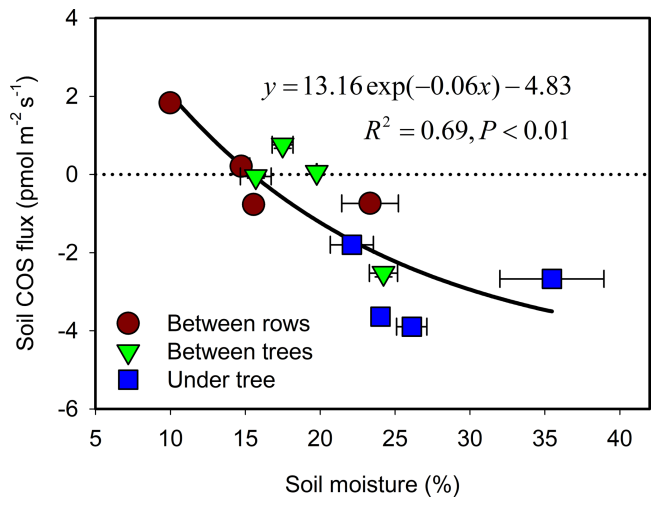

Figure 2. Relationship of soil COS flux and soil moisture. Each data point represents the diurnal average $(N=24)$ for each micro-site and season (measurement campaign). Error bars represent $\pm 1 \mathrm{SE}$ around the mean; errors for flux are about the size of the symbols.

respectively (Fig. 1). On average, soil COS fluxes showed a nonlinear increase in uptake with increasing $\theta$, but it seems that this response may saturate at about $\theta$ of $25 \%$ and uptake rates of $\sim-3.9 \mathrm{pmol} \mathrm{m}^{-2} \mathrm{~s}^{-1}$ (Fig. 2). The fit to the data presented in Fig. 2 also indicate that in dry soil with $\theta<15 \%$, soil COS emission can be expected.

The response of soil COS fluxes to soil temperature varied among the three measurement sites (Fig. 3). The BT and BR sites showed a near-linear response with a shift from uptake to emission around $25^{\circ} \mathrm{C}$. At the shaded and moist UT site, $\mathrm{COS}$ uptake was always significant, ranging between -4 and $-1 \mathrm{pmol} \mathrm{m}^{-1} \mathrm{~s}^{-1}$ with relatively low temperature sensitivity, and with lowest mean uptake rates around $20^{\circ} \mathrm{C}$.

Pearson product-moment correlation analysis results showed that hourly soil COS flux was significantly related to soil moisture and temperature (at the 0.001 level), and the soil moisture had stronger environmental controls on the soil COS flux $(r=-0.77)$ than soil temperature $(r=+0.45)$.

A comprehensive assessment of the effects of soil moisture $(\theta)$, temperature $\left(T_{\mathrm{S}}\right)$ and distance from tree trunk $(d)$ showed that hourly soil COS flux $\left(F_{\mathrm{COS}}\right)$ could be fitted to a three-

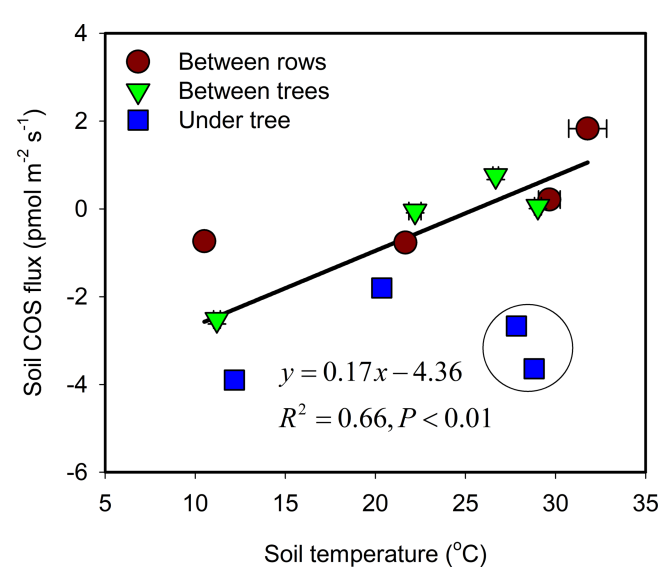

Figure 3. Soil COS flux as a function of temperature and its linear regression line. Each data point represents the diurnal average $(N=$ $24)$ for each site and season (campaign). Error bars $\pm 1 \mathrm{SE}$ around the mean. The data points marked by black circle were collected during irrigation cycle (enhanced uptake) and were excluded from the regression.

parameter exponential model, which could explain $75 \%$ of the variation in soil COS flux (Eq. 6).

$$
\begin{gathered}
F_{\mathrm{COS}}=8.91 \exp \left(0.01 T_{\mathrm{s}}-0.01 \theta+0.09 d-0.33\right)-8.86 \\
R^{2}=0.75
\end{gathered}
$$

\subsection{COS flux estimates from soil concentration gradients}

The average soil concentration gradient of $\mathrm{COS}$ and $\mathrm{CO}_{2}$ for the four campaigns is shown in Fig. 4. COS concentrations decreased with soil depth, with the opposite trend for $\mathrm{CO}_{2}$, consistent with the results reported above of soil surface COS uptake and $\mathrm{CO}_{2}$ emission at our orchard site. $\mathrm{COS}$ concentrations at a depth of $2.5 \mathrm{~cm}$ were on average $314 \mathrm{ppt}$, about onethird lower than the mean surface ambient value of $460 \mathrm{ppt}$. The lowest COS concentration at a depth of $20 \mathrm{~cm}$ (166 ppt) was almost one-third of that at the soil surface. An expo- 
Table 1. Mean values of soil $\mathrm{COS}$ and $\mathrm{CO}_{2}$ flux rates across sites (BR, between rows; BT, between trees; UT, under tree) and seasons, together with the normalized ratio of $\operatorname{COS} / \mathrm{CO}_{2}$ fluxes (SRU), the mean soil temperature at $5 \mathrm{~cm}$ depth $\left(T_{\mathrm{S}}\right)$ and soil water content $(\%$ wt; $\theta$ ).

\begin{tabular}{lcrrrrr}
\hline Campaigns & Sites & $\begin{array}{r}\mathrm{COS} \text { flux } \\
\left(\mathrm{pmol} \mathrm{m}^{-2} \mathrm{~s}^{-1}\right)\end{array}$ & $\begin{array}{r}\mathrm{CO}_{2} \text { flux } \\
\left(\mu \mathrm{mol} \mathrm{m} \mathrm{s}^{-2}\right)\end{array}$ & SRU & $\begin{array}{r}T_{\mathrm{S}} \\
\left({ }^{\circ} \mathrm{C}\right)\end{array}$ & $\begin{array}{r}\theta \\
(\%)\end{array}$ \\
\hline August 2015 & BR & $1.83 \pm 0.08$ & $0.77 \pm 0.04$ & 1.85 & $31.66 \pm 1.01$ & $9.98 \pm 0.28$ \\
& $\mathrm{BT}$ & $0.06 \pm 0.05$ & $3.33 \pm 0.05$ & 0.01 & $29.09 \pm 0.20$ & $19.77 \pm 0.02$ \\
& $\mathrm{UT}$ & $-3.64 \pm 0.13$ & $10.79 \pm 0.12$ & -0.26 & $28.80 \pm 0.26$ & $24.03 \pm 0.40$ \\
\hline December 2015 & $\mathrm{BR}$ & $-0.74 \pm 0.07$ & $0.30 \pm 0.02$ & -1.92 & $10.50 \pm 0.17$ & $23.33 \pm 1.89$ \\
& $\mathrm{BT}$ & $-2.52 \pm 0.10$ & $1.21 \pm 0.03$ & -1.62 & $11.20 \pm 0.19$ & $24.22 \pm 0.94$ \\
& $\mathrm{UT}$ & $-3.87 \pm 0.08$ & $3.81 \pm 0.07$ & -0.79 & $12.17 \pm 0.16$ & $26.11 \pm 1.01$ \\
\hline May 2016 & BR & $-0.77 \pm 0.02$ & $0.32 \pm 0.02$ & -1.88 & $21.67 \pm 0.32$ & $15.56 \pm 0.38$ \\
& $\mathrm{BT}$ & $-0.05 \pm 0.04$ & $1.31 \pm 0.05$ & -0.03 & $22.20 \pm 0.34$ & $15.70 \pm 1.03$ \\
& $\mathrm{UT}$ & $-1.80 \pm 0.11$ & $10.78 \pm 0.54$ & -0.13 & $20.35 \pm 0.38$ & $22.11 \pm 1.44$ \\
\hline July 2016 & BR & $0.21 \pm 0.04$ & $0.79 \pm 0.05$ & 0.21 & $29.66 \pm 0.60$ & $14.73 \pm 0.57$ \\
& $\mathrm{BT}$ & $0.76 \pm 0.09$ & $1.97 \pm 0.04$ & 0.30 & $26.68 \pm 0.15$ & $17.49 \pm 0.70$ \\
& $\mathrm{UT}$ & $-2.67 \pm 0.09$ & $14.58 \pm 0.40$ & -0.14 & $27.83 \pm 0.34$ & $35.47 \pm 3.47$ \\
\hline
\end{tabular}

nential and a linear equation provided a reasonable fit to the changes in soil $\mathrm{COS}$ and $\mathrm{CO}_{2}$ concentrations, respectively, as a function of depth $\left(z_{\text {soil }}\right)$ :

$$
\begin{aligned}
{[\mathrm{COS}]=} & 283.5 \exp \left(-0.2 z_{\text {soil }}\right)+169.9, R^{2}=0.99, \\
& {\left[\mathrm{CO}_{2}\right]=122.2 z_{\text {soil }}+558.5, R^{2}=0.99 . }
\end{aligned}
$$

In terms of individual sites and campaigns, all profiles except for BR in summer (June) showed the general trend of decreasing $[\mathrm{COS}]$ and increasing $\left[\mathrm{CO}_{2}\right]$ with depth, with the steepest gradient in the top $5 \mathrm{~cm}$ (Fig. 5). At the BR microsite in summer, $\mathrm{CO}_{2}$ profiles were shallow, consistent with low respiration (see July BR in Table 1). But a decrease in COS concentration toward the surface, with a surface value lower than the next two soil depth points (Fig. 5j), was consistent with COS emission at that time (July BR in Table 1).

As noted above, the profile data generally exhibited the steepest gradient in the top few centimeters of the soil, indicating that the dominating COS sink (and likely also the $\mathrm{CO}_{2}$ source) was located at shallow depth. We therefore used the gas concentration difference at the two shallowest depths $\left(z_{\text {soil } 1}=0\right.$ and $\left.z_{\text {soil } 2}=2.5 \mathrm{~cm}\right)$ to provide an approximation of the fluxes to and from the soil to constrain the more extensive chamber measurements. The COS diffusion coefficient, $D_{\mathrm{s}}$, was estimated for each campaign (see "Materials and methods"), indicating a low $D_{\mathrm{s}}$ value at the UT site in June and July $\left(D_{\mathrm{s}}=2.55 \mathrm{~mm}^{2} \mathrm{~s}^{-1}\right)$ associated with the drip irrigation and the high soil water content and high values in the dryer soils $\left(D_{\mathrm{s}}=5.57 \mathrm{~mm}^{2} \mathrm{~s}^{-1}\right)$, with an average COS diffusion coefficient of $4.4 \pm 0.3 \mathrm{~mm}^{2} \mathrm{~s}^{-1}$. The soil COS flux estimates using the gradient method are reported in Table 2. COS flux varied between -2.1 and $+1.6 \mathrm{pmol} \mathrm{m}^{-2} \mathrm{~s}^{-1}$ with a mean value of $-1.0 \pm 0.3 \mathrm{pmol} \mathrm{m}^{-2} \mathrm{~s}^{-1}$ during the measurement periods, consistent with the mean value of $1.1 \pm 0.1 \mathrm{pmol} \mathrm{m}^{-2} \mathrm{~s}^{-1}$ reported above for the chamber mea-

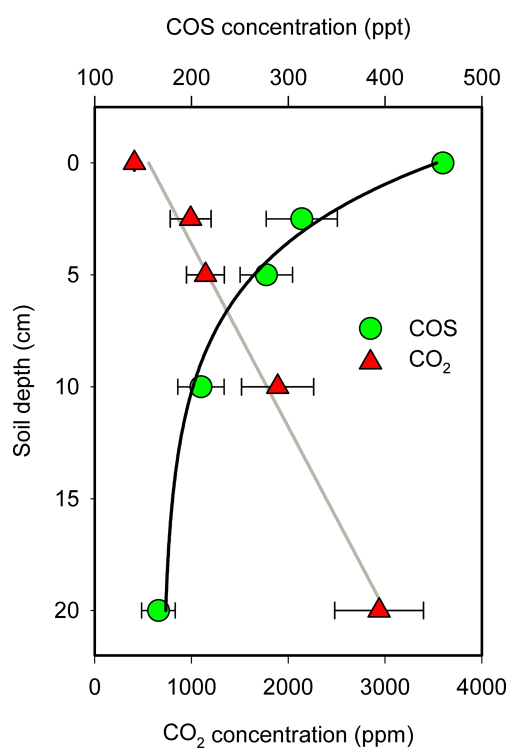

Figure 4. Mean $\mathrm{COS}$ and $\mathrm{CO}_{2}$ concentrations at different soil depths. The COS concentration decreases exponentially with soil depth. The data point is the mean of the combined data at each of the four measurement campaigns $(N=4 ; \pm 1 \mathrm{SE})$.

surements. Also in agreement with the chamber measurements, fluxes at UT and BT always showed COS uptake, with generally higher values in spring (March) than in summer (May-June), while the BR data indicated change from uptake in spring (March-April, -1.3 to $-1.6 \mathrm{pmol} \mathrm{m}^{-2} \mathrm{~s}^{-1}$ ) to emission in June $\left(+1.6 \mathrm{pmol} \mathrm{m}^{-2} \mathrm{~s}^{-1}\right)$.

\subsection{Soil relative uptake}

Soil was always a source of $\mathrm{CO}_{2}$ due to respiration (combined autotrophic and heterotrophic respiration). Soil $\mathrm{CO}_{2}$ 
Table 2. Estimates of soil $\mathrm{COS}$ and $\mathrm{CO}_{2}$ fluxes from soil concentration gradient measurements ( $T_{\mathrm{s}}$, soil temperature; $\theta$, soil water content; $\mathrm{BR}$, between rows; BT, between trees; UT, under tree).

\begin{tabular}{lcrrrrrr}
\hline Campaigns & Sites & $\begin{array}{r}\mathrm{COS} \text { flux } \\
\left(\mathrm{pmol} \mathrm{m}^{-2} \mathrm{~s}^{-1}\right)\end{array}$ & $\begin{array}{r}\mathrm{CO}_{2} \text { flux } \\
\left(\mu \mathrm{mol} \mathrm{m}^{-2} \mathrm{~s}^{-1}\right)\end{array}$ & $\begin{array}{r}\mathrm{CO}_{2} \text { diffusion } \\
\text { coefficient } \\
\left(\mathrm{mm}^{2} \mathrm{~s}^{-1}\right)\end{array}$ & $\begin{array}{r}\mathrm{COS} \text { diffusion } \\
\text { coefficient } \\
\left(\mathrm{mm}^{2} \mathrm{~s}^{-1}\right)\end{array}$ & $\begin{array}{r}T_{\mathrm{S}} \\
\left({ }^{\circ} \mathrm{C}\right)\end{array}$ & $\begin{array}{r}\theta \\
(\%)\end{array}$ \\
\hline March 2016 & BR & -1.31 & 2.34 & 5.21 & 4.40 & 17.9 & 19.4 \\
& $\mathrm{BT}$ & -1.15 & 2.21 & 4.80 & 4.05 & 16.2 & 21.8 \\
& $\mathrm{UT}$ & -2.10 & 5.89 & 4.76 & 4.02 & 17.3 & 22.4 \\
\hline April 2016 & BR & -1.55 & 1.07 & 6.66 & 5.62 & 23.0 & 11.0 \\
& BT & -0.89 & 1.14 & 6.44 & 5.43 & 20.4 & 11.6 \\
& UT & -1.74 & 4.73 & 6.01 & 5.07 & 22.4 & 15.2 \\
\hline May 2016 & BR & -0.98 & 2.21 & 5.68 & 4.79 & 21.9 & 17.4 \\
& BT & -0.51 & 1.24 & 5.06 & 4.27 & 22.0 & 21.6 \\
& UT & -1.20 & 11.36 & 3.11 & 2.63 & 20.1 & 34.5 \\
\hline June 2016 & BR & 1.55 & 2.63 & 6.61 & 5.57 & 35.9 & 15.5 \\
& BT & -1.17 & 2.60 & 5.20 & 4.39 & 26.3 & 21.7 \\
& UT & -1.19 & 11.85 & 3.02 & 2.55 & 22.9 & 35.6 \\
\hline
\end{tabular}

flux rates varied both spatially and temporally in similar patterns to those of COS and with an overall range of +0.3 to $+14.6 \mu \mathrm{mol} \mathrm{m}^{-2} \mathrm{~s}^{-1}$ (Table 1). The highest soil respiration values were observed at the UT sites in summer (July, August; Table 1), with intermediate $(+1$ to about $\left.+3 \mu \mathrm{mol} \mathrm{m}^{-2} \mathrm{~s}^{-1}\right)$ and low values $\left(<+1 \mu \mathrm{mol} \mathrm{m}^{-2} \mathrm{~s}^{-1}\right)$ at the BT and BR sites, respectively. Generally, soil COS exchange varied from release to increasing uptake with increasing $\mathrm{CO}_{2}$ production in a nonlinear way (Fig. 6a). The normalized ratio of $\mathrm{COS}$ to $\mathrm{CO}_{2}$ fluxes (SRU; Eq. 2) varied from -1.9 to +1.9 , with an average value of $-0.4 \pm 0.3$, with negative values indicating $\mathrm{COS}$ uptake linked to $\mathrm{CO}_{2}$ emission. SRU values showed a response to both soil temperature (Fig. 6b) and soil moisture (Fig. 6c), although with relatively low $R^{2}$ values. Respiration increased with temperature while COS uptake declined, and at temperatures above about $25^{\circ} \mathrm{C}$, SRU turned positive when both $\mathrm{COS}$ and $\mathrm{CO}_{2}$ were emitted from the soil. SRU exhibited inverse relationships with soil moisture, with positive values in dry soil and increasingly negative values with increasing soil moisture (Fig. 6c). Based on its combined temperature $\left(T_{\mathrm{S}}\right)$ and moisture $(\theta)$ response, SRU could be forecasted by the following algorithm, which explained $67 \%$ of the observed variations (Eq. 8):

$\mathrm{SRU}=0.01 \exp \left(0.17 T_{\mathrm{S}}\right)-0.02 \theta-1.00, R^{2}=0.67$.

ANOVA results indicated that SRU was not significantly different among the three observation micro-sites (BR, BT and UT; $P>0.05$ ). Between the seasonal campaigns, however, SRU values peaked in summer $(+0.5 \pm 0.7)$, with the highest averaged soil temperature $\left(29^{\circ} \mathrm{C}\right)$, and were significantly higher than winter SRU $(-1.4 \pm 0.6)$ when soil temperature was lowest $\left(11^{\circ} \mathrm{C} ; P<0.05\right)$. There was no significant difference in SRU among the other campaigns $(P>0.05)$.

\section{Discussions}

\subsection{Heterogeneity in soil COS exchange}

The observed soil-atmosphere COS exchange rates observed in this study (both mean and range; Fig. 1, Table 1) are consistent with values reported in a range of other ecosystems $\left(-1.4\right.$ to $-4.9 \mathrm{pmol} \mathrm{m}^{-2} \mathrm{~s}^{-1}$; Steinbacher et al., 2004; Kitz et al., 2017; White et al., 2010; Berkelhammer et al., 2014) but lower than -11.0 to $-11.8 \mathrm{pmol} \mathrm{m}^{-2} \mathrm{~s}^{-1}$ in riparian and subtropical forests (Berkelhammer et al., 2014; Yi et al., 2007). Soil COS emissions were also observed in the summer and spring campaigns, with maximal COS emission consistent with the values of +1.8 to $+2.6 \mathrm{pmol} \mathrm{m}^{-2} \mathrm{~s}^{-1}$ observed in riparian and alpine forests (Berkelhammer et al., 2014) but significantly lower than reported in the senescing agricultural ecosystem $\left(\sim+30 \mathrm{pmol} \mathrm{m}^{-2} \mathrm{~s}^{-1}\right.$; Maseyk et al., 2014).

The observed range in the soil-atmosphere exchange fluxes reflected significant heterogeneity on both the spatial and the temporal scales. The spatial-scale heterogeneity clearly reflected the contrasting micro-site conditions with lower temperatures and higher moisture under the trees (UT sites) compared with the higher temperatures and lower moisture in exposed soil between rows (BR sites), with intermediate, partially shaded, conditions between trees (BT sites). Indeed, a large fraction of the variations in the COS flux $(\sim 75 \%)$ could be explained by a simple algorithm as a function of these two variables: temperature and moisture. Note that while temperature and $\theta$ covaried in general, with high temperatures associated with drier soil, under the wet UT conditions, sensitivity to temperature was significantly reduced. In the dry soil conditions, emission was associated with high temperature and at the BR sites also with high solar radiation. However, all measurements were made in dark 


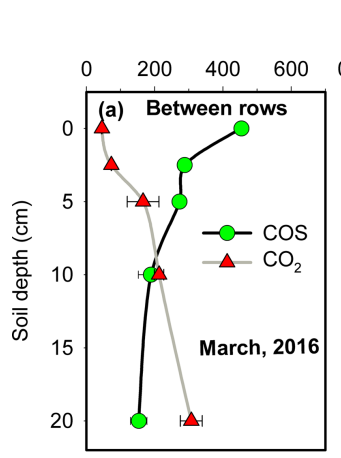

COS concentration (ppt)
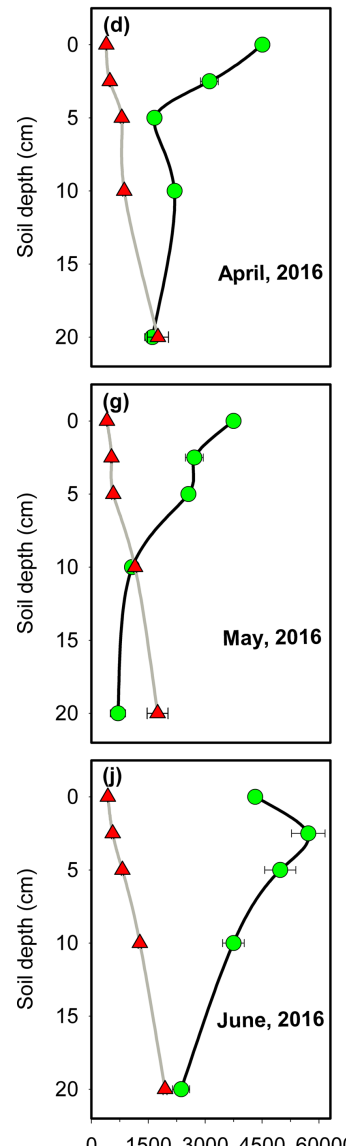

$015003000450060000 \quad 15003000450060000$

$\mathrm{CO}_{2}$ concentration (ppm)

Figure 5. Soil $\mathrm{COS}$ and $\mathrm{CO}_{2}$ concentration profiles at the three micro-sites in four measurement campaigns. The data points are the mean of all measurements in a campaign $(N=4, \pm 1 \mathrm{SE})$.

chambers and could not involve photochemical production, which was also demonstrated in agricultural soil by Kitz et al. (2017). Apparently even under dark conditions, high temperature can induce high emission rates, as also noted when the thermal insolation on the soil chamber at the BR site was occasionally removed and a large spike in temperature $\left(52^{\circ} \mathrm{C}\right)$ and emission of $11.4 \mathrm{pmol} \mathrm{m}^{-2} \mathrm{~s}^{-1}$ was observed. Note also that the soil profile results indicated that the emission source was below the surface and maybe nonphotochemical irrespective of the chamber opaqueness.

Temporal variations were observed both on the daily and seasonal timescales. Diurnal changes were, however, minor compared to the changes from winter to summer at all microsites. Shifts from uptake to emission were observed essentially only on the seasonal timescale (Fig. 1). This likely reflected the dominance of soil moisture in relation to the $\operatorname{COS}$ flux rates. This is because $\theta$ did not change noticeably on the daily scale, while it did changed considerably across seasons (between 10.0 and $35.5 \%$ overall). Soil temperatures did change over the daily cycle (e.g., 26.0 to $42.4^{\circ} \mathrm{C}$ at the BR site during summer), although such changes are still smaller than the seasonal changes in soil temperature (e.g., 10.5 to $31.8^{\circ} \mathrm{C}$ at the $\mathrm{BR}$ site). A dominant role of soil moisture in explaining the variations in COS uptake is consistent with the results of Van Diest and Kesselmeier (2008) but less so with the negligible $\theta$ effects in grassland under simulated drought (Kitz et al., 2017).

COS uptake is thought to be related to carbonic anhydrase (CA) activity in soil (Kesselmeier et al., 1999), which could be via microorganisms (Piazzetta et al., 2015), such as bacteria (Kamezaki et al., 2016; Kato et al., 2008) or fungi (Bunk et al., 2017; Li et al., 2010; Masaki et al., 2016). CA activity is also influenced by soil moisture (Davidson and Janssens, 2006; Seibt et al., 2006), although soil moisture can also directly influence soil gas diffusion rates (Ogée et al., 2016; Sun et al., 2015). The effect of CA on COS exchange can also be related to root distribution and the effects of CA activity within plant roots (Seibt et al., 2006; Viktor and Cramer, 2005; Whelan and Rhew, 2015). This could influence the spatial variations and soil moisture effects on COS exchange in this study as most of the roots were distributed around the restricted trees' drip irrigation zone at UT sites and were sparse in the dryer areas, such as the BR and BT sites (unquantified observations).

At least part of the variations in soil COS fluxes could also reflect the differential effects of environmental conditions on COS uptake and production process (Ogée et al., 2016). Solubility in soil water (with a COS solubility of $0.8 \mathrm{~mL} \mathrm{~mL}^{-1}$; Svoronos and Bruno, 2002) could also be significant, especially at the UT micro-sites, influenced by the drip irrigation from May to September, which could involve water percolation to deeper soil layers. The drivers of soil COS production are still unclear. COS could be produced by chemical processes in the lab (Ferm, 1957) but can also be produced by biotic process in soils such as hydrolysis of metallic thiocyanates (Katayama et al., 1992) with thiocyanate hydrolase (Conrad, 1996; Svoronos and Bruno, 2002) and hydrolysis of $\mathrm{CS}_{2}$ (Cox et al., 2013; Smith and Kelly, 1988). Fungi are also reported to be the source of COS (Masaki et al., 2016). Additionally, abiotic thermal degradation of organic matter leading to COS production may be consistent with the temperature sensitivity of COS emission at the BR micro-site where biotic processes can be expected to be minimized. Similar 

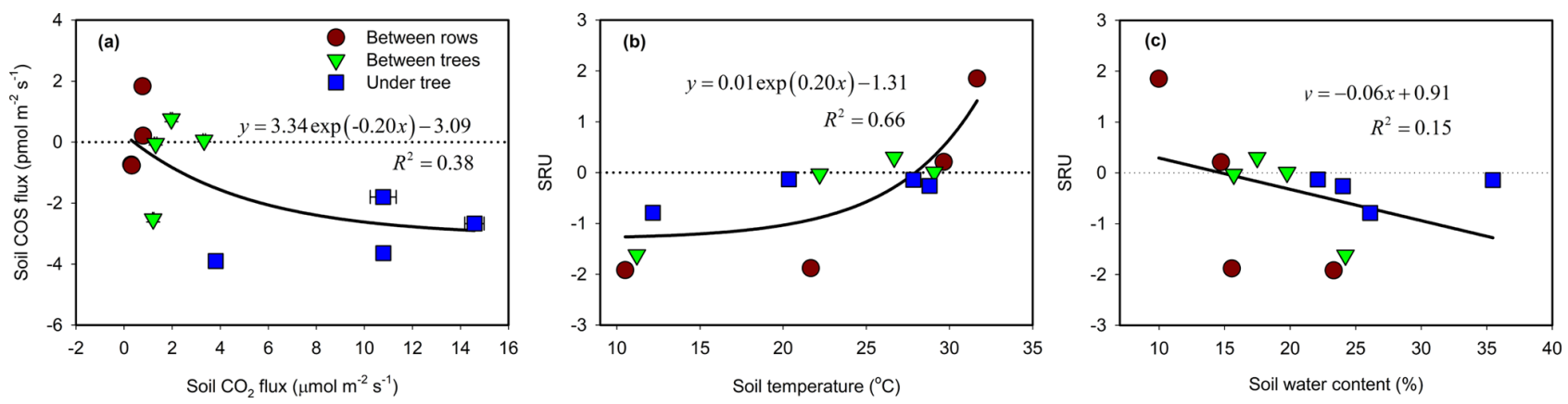

Figure 6. The relationships between soil $\mathrm{COS}$ and $\mathrm{CO}_{2}$ flux rates (chamber measurements a). The response of soil relative uptake (SRU; normalized ratio of $\mathrm{COS}$ to $\mathrm{CO}_{2}$ fluxes) to soil temperature (b) and to soil water content (c). The data points represent the diurnal average $(N=24)$ of each site and season (measurement campaign). Error bars represent $\pm 1 \mathrm{SE}$ around the mean (often the size of the symbol).

high temperature-dependent soil COS emissions were reported in midlatitude forests (Commane et al., 2015) and an agricultural field (Maseyk et al., 2014). Lab incubation results also indicated thermal production of COS in soil with increasing temperature (Liu et al., 2010; Whelan et al., 2016; Whelan and Rhew, 2015). Photochemical production of soil COS was also proposed (Sun et al., 2015; Whelan and Rhew, 2015), and assumed to be driven by ultraviolet fraction of incoming solar radiation (Kitz et al., 2017). Note, however, that all measurements in the present study were made in the dark. In addition, the chemical reaction of $\mathrm{CO}$ and $\mathrm{MgSO}_{4}$ under heating could also produce COS (Ferm, 1957). Note that $\mathrm{MgSO}_{4}$ has been reported in our study soil (Singer, 2007), and we observed a relatively high $\mathrm{CO}$ concentration at our field site (not shown due to insufficient calibration). Finally, the balance between the uptake (likely biotically dominated) and emission (likely abiotically dominated) can also be influenced by soil nitrogen (Kaisermann et al., 2018).

\subsection{Soil relative uptake}

We use SRU values to assess the relative importance of the soil COS flux compared with the canopy and indicate shifts from conservative links between processes influencing COS and $\mathrm{CO}_{2}$ (see the Introduction). On average, the value of SRU at our site was smaller than reported for riparian or pine forests $(-0.37$ vs. -0.76 and -1.08 ; Berkelhammer et al., 2014; Sun et al., 2018). This may reflect the contribution of COS emissions at BR and BT in summer that were not observed in the forest study. Overall, the mean SRU values observed here indicated that the soil COS uptake flux was proportionally less than $40 \%$ of the soil respiration flux. In contrast with the canopy fluxes where the COS uptake flux is proportionally nearly twice as large as the $\mathrm{CO}_{2}$ assimilation flux (LRU 1.6 at our site; Yang et al., 2018; 1.7 across vegetation types, Whelan et al., 2018). In contrast to leaves with robust LRU values that tend toward a constant, SRU at our site varied between -1.9 and +1.9 . However, this range was observed only at the dryer and exposed BR sites, while in the shaded and moist UT sites, it was much narrower: -0.1 to -0.8 . Furthermore, it seems that the high SRU values (both positive and negative) represented conditions where the actual fluxes were small (COS uptake was on average -3.0 in the UT but only $0.1 \mathrm{pmol} \mathrm{m}^{-2} \mathrm{~s}^{-1}$ at the BR sites). It seems that the large SRU values at the BR micro-sites were also associated with low soil respiration: $0.5 \mu \mathrm{mol} \mathrm{m}^{-2} \mathrm{~s}^{-1}$ at BR sites compared to $10 \mu \mathrm{mol} \mathrm{m}{ }^{-2} \mathrm{~s}^{-1}$ at the UT sites. It is therefore possible that the low SRU values are more significant for ecosystem-scale studies and indicate a much smaller contribution to overall ecosystem fluxes than those of the canopy (i.e., SRU $\sim-0.4$ vs. LRU $\sim+1.7$ ).

The differential effects of changing environmental conditions on production and uptake processes were reflected in the relatively large spatial and temporal heterogeneity observed in the soil COS exchange at our site. However, the contrasting effects of production and emission may explain both the sharp increase in SRU values at high temperatures, as the effects of production counteract uptake (Fig. 6b), and the much lower sensitivity to temperature of COS flux compared to that of $\mathrm{CO}_{2}$ (Fig. 6a). Such contrasting consumption or production effects may, in fact, reduce the magnitude of the net flux of soil COS and may explain the relatively narrow range of SRU values.

The application of $\mathrm{COS}$ as a tracer for canopy $\mathrm{CO}_{2}$ exchange requires accounting for the soil effects, and while knowledge of SRU can help predict it, ultimately we need to quantify the fluxes. Note in that respect that in our recent canopy-scale study at the same site, Yang et al. (2018) indicated that in spite of the considerable variations in soil COS fluxes, the soil COS uptake fluxes were equivalent to $\sim 1 \%$ of the daytime foliage flux across seasons and reached $\sim 3 \%$ in the spring peak season (but larger proportions were observed during more stressful periods when fluxes were overall small). 


\subsection{Soil COS profiles}

Complementing our chamber measurements with soil profile measurements of $\mathrm{COS}$ and $\mathrm{CO}_{2}$ concentrations provided constraints on the relatively new surface soil COS measurements and provided additional information on the possible location of the source or sink in the soil. Using the nearsurface gradient yielded flux estimates comparable to chamber measurements, providing a useful and rare quantitative validation. For example, in May, the chamber and profile measurements were made at about the same time (5-9 May for chamber and 10 May for profile), and the differences between chamber (all micro-sites) and gradient flux estimates was negligible $\left(\sim 0.2-0.6 \mathrm{pmol} \mathrm{m}^{-2} \mathrm{~s}^{-1}\right)$. However, the profile results also indicated that the sink or source activities were concentrated in the top soil layers, probably at around $5-10 \mathrm{~cm}$ depth, as reflected in the minimum or maximum in gas concentrations (emphasizing the need for a high vertical resolution in employing the profile approach). The variable profiles observed below these points must reflect temporal dynamics in the sink or source activities across the profile. The near-surface peak activity makes it particularly sensitive to variations in temperature and moisture, as observed (Figs. 2 and 3). Low COS concentration in the lower parts of the profile may result from the continuous removal of soil $\mathrm{COS}$ and may indicate a distribution of CA activity beyond the litter layer and the soil surface (Seibt et al., 2006). COS production, however, seems to occur only near the soil surface with no indication for production in deeper layers, consistent with its high temperature sensitivity and not necessarily dependent on radiation (e.g., Kitz et al., 2017).

Note that the gradient method based on the Fick's diffusion law has its own limitations (Kowalski and Sánchezcañete, 2010; Sánchez-Cañete et al., 2017; Bekele et al., 2007). However, it is a simple, low-cost approach and can help diagnose the magnitude of soil fluxes, which can also help in identifying belowground processes and their locations.

\section{Conclusions}

Our detailed analysis of the spatial and temporal variations in soil-atmosphere exchange of COS provided new information on a key uncertainty in the application of ecosystem COS flux to assess productivity. Furthermore, we provide validation of the surface chamber measurements that are generally in use, by the additional gradient approach. Our results show that both micro-sites and seasonal variations in COS fluxes were related to soil moisture, temperature and the distance from the tree (likely reflecting root distribution), but we suggest that soil moisture is the predominant environmental control over soil COS exchanges at our site. A simple algorithm was sufficient to forecast most of the variations in soil COS flux, supporting its incorporated into ecosystem-scale appli- cations, as we recently demonstrated in a parallel study at the same site (Yang et al., 2018).

Clearly, uncertainties are still associated with soil processes involving COS, the differential effects of soil moisture, temperature and communities of microorganisms, and they are likely to contribute to both the spatial and temporal variations in soil net $\mathrm{COS}$ exchange and require further research.

Data availability. The data used in this study are archived and available from the corresponding author upon request (dan.yakir@weizmann.ac.il).

Author contributions. DY designed the study; FY, RQ, FT, RS and DY performed the experiments. FY and FT analyzed the data. DY and FY wrote the paper with discussions and contributions to interpretations of the results from all coauthors.

Competing interests. The authors declare that they have no conflict of interest.

Acknowledgements. We are grateful to Omri Garini, Madi Amer and Boaz Ninyo-Setter for their help. This work was supported by the Minerva foundation, a joint NSFC-ISF grant 2579/16, the Israel Science Foundation (ISF 1976/17), the German Research Foundation (DFG) as part of the CliFF Project and the JNF-KKL. Fulin Yang is supported by the National Natural Science Foundation of China (41775105) and the Natural Science Foundation of Gansu Province (17JR5RA341).

Review statement. This paper was edited by Janne Rinne and reviewed by Mary E. Whelan and one anonymous referee.

\section{References}

Asaf, D., Rotenberg, E., Tatarinov, F., Dicken, U., Montzka, S. A., and Yakir, D.: Ecosystem photosynthesis inferred from measurements of carbonyl sulphide flux, Nat. Geosci., 6, 18-190, 2013.

Bekele, A., Kellman, L., and Beltrami, H.: Soil Profile $\mathrm{CO}_{2}$ concentrations in forested and clear cut sites in Nova Scotia, Canada, Forest. Ecol. Manag., 242, 587-597, 2007.

Berkelhammer, M., Asaf, D., Still, C., Montzka, S., Noone, D., Gupta, M., Provencal, R., Chen, H., and Yakir, D.: Constraining surface carbon fluxes using in situ measurements of carbonyl sulfide and carbon dioxide, Global Biogeochem. Cy., 28, 161-179, 2014.

Berry, J., Wolf, A., Campbell, J. E., Baker, I., Blake, N., Blake, D., Denning, A. S., Kawa, S. R., Montzka, S. A., and Seibt, U.: A coupled model of the global cycles of carbonyl sulfide and $\mathrm{CO}_{2}$ : A possible new window on the carbon cycle, J. Geophys. Res.Biogeosci., 118, 842-852, 2013. 
Bunk, R., Behrendt, T., Yi, Z., Andreae, M. O., and Kesselmeier, J.: Exchange of carbonyl sulfide (OCS) between soils and atmosphere under various $\mathrm{CO}_{2}$ concentrations, J. Geophys. Res.Biogeosci., 122, 1343-1358, 2017.

Commane, R., Meredith, L. K., Baker, I. T., Berry, J. A., Munger, J. W., Montzka, S. A., Templer, P. H., Juice, S. M., Zahniser, M. S., and Wofsy, S. C.: Seasonal fluxes of carbonyl sulfide in a midlatitude forest, P. Natl. Acad. Sci. USA, 112, 14162-14167, 2015.

Conrad, R.: Soil microorganisms as controllers of atmospheric trace gases $\left(\mathrm{H}_{2}, \mathrm{CO}, \mathrm{CH}_{4}, \mathrm{OCS}, \mathrm{N}_{2} \mathrm{O}\right.$, and $\left.\mathrm{NO}\right)$, Microbiol. Rev., 60, 609-640, 1996.

Cox, S. F., McKinley, J. D., Ferguson, A. S., O’Sullivan, G., and Kalin, R. M.: Degradation of carbon disulphide $\left(\mathrm{CS}_{2}\right)$ in soils and groundwater from a $\mathrm{CS}_{2}$-contaminated site, Environ. Earth Sci., 68, 1935-1944, 2013.

Davidson, E. A. and Janssens, I. A.: Temperature sensitivity of soil carbon decomposition and feedbacks to climate change, Nature, 440, 165-173, 2006.

Ferm, R. J.: The chemistry of carbonyl sulfide, Chem. Rev., 57, 621-640, 1957.

Jones, H. G.: Plants and Microclimate: A Quantitative Approach to Environmental Plant Physiology, 3rd edition, Cambridge University Press, 2013.

Kaisermann, A., Ogée, J., Sauze, J., Wohl, S., Jones, S. P., Gutierrez, A., and Wingate, L.: Disentangling the rates of carbonyl sulfide (COS) production and consumption and their dependency on soil properties across biomes and land use types, Atmos. Chem. Phys., 18, 9425-9440, https://doi.org/10.5194/acp18-9425-2018, 2018.

Kamezaki, K., Hattori, S., Ogawa, T., Toyoda, S., Kato, H., Katayama, Y., and Yoshida, N.: Sulfur Isotopic Fractionation of Carbonyl Sulfide during Degradation by Soil Bacteria, Environ. Sci. Technol., 50, 3537-3544, 2016.

Kapiluto, Y., Dan, Y., Tans, P., and Berkowitz, B.: Experimental and numerical studies of the ${ }^{18} \mathrm{O}$ exchange between $\mathrm{CO}_{2}$ and water in the atmosphere-soil invasion flux, Geochim. Cosmochim. Ac., 71, 2657-2671, 2007.

Katayama, Y., Narahara, Y., Inoue, Y., Amano, F., Kanagawa, T., and Kuraishi, H.: A thiocyanate hydrolase of Thiobacillus thioparus. A novel enzyme catalyzing the formation of carbonyl sulfide from thiocyanate, J. Biol. Chem., 267, 9170-9175, 1992.

Kato, H., Saito, M., Nagahata, Y., and Katayama, Y.: Degradation of ambient carbonyl sulfide by Mycobacterium spp. in soil, Microbiology, 154, 249-255, 2008.

Kesselmeier, J., Teusch, N., and Kuhn, U.: Controlling variables for the uptake of atmospheric carbonyl sulfide by soil, J. Geophys. Res.-Atmos., 104, 11577-11584, 1999.

Kitz, F., Gerdel, K., Hammerle, A., Laterza, T., Spielmann, F. M., and Wohlfahrt, G.: In situ soil COS exchange of a temperate mountain grassland under simulated drought, Oecologia, 183, 851-860, 2017.

Kooijmans, L. M. J., Uitslag, N. A. M., Zahniser, M. S., Nelson, D. D., Montzka, S. A., and Chen, H.: Continuous and high-precision atmospheric concentration measurements of $\mathrm{COS}, \mathrm{CO}_{2}, \mathrm{CO}$ and $\mathrm{H}_{2} \mathrm{O}$ using a quantum cascade laser spectrometer (QCLS), Atmos. Meas. Tech., 9, 5293-5314, https://doi.org/10.5194/amt-95293-2016, 2016.
Kowalski, A. S. and Sánchezcañete, E. P.: A New Definition of the Virtual Temperature, Valid for the Atmosphere and the $\mathrm{CO}_{2}$-Rich Air of the Vadose Zone, J. Appl. Meteorol. Clim., 49, 12381242, 2010.

Kuhn, U., Ammann, C., Wolf, A., Meixner, F., Andreae, M., and Kesselmeier, J.: Carbonyl sulfide exchange on an ecosystem scale: Soil represents a dominant sink for atmospheric COS, Atmos. Environ., 33, 995-1008, 1999.

Li, X., Liu, J., and Yang, J.: Variation of $\mathrm{H}_{2} \mathrm{~S}$ and COS emission fluxes from Calamagrostis angustifolia Wetlands in Sanjiang Plain, Northeast China, Atmos. Environ., 40, 6303-6312, 2006.

Li, X. S., Sato, T., Ooiwa, Y., Kusumi, A., Gu, J. D., and Katayama, Y.: Oxidation of elemental sulfur by Fusarium solani strain THIF01 harboring endobacterium Bradyrhizobium sp, Microbiol. Ecol., 60, 96-104, 2010.

Liu, J., Geng, C., Mu, Y., Zhang, Y., Xu, Z., and Wu, H.: Exchange of carbonyl sulfide (COS) between the atmosphere and various soils in China, Biogeosciences, 7, 753-762, https://doi.org/10.5194/bg-7-753-2010, 2010.

Masaki, Y., Ozawa, R., Kageyama, K., and Katayama, Y.: Degradation and emission of carbonyl sulfide, an atmospheric trace gas, by fungi isolated from forest soil, FEMS Microbiol. Lett., 363, fnw197, https://doi.org/10.1093/femsle/fnw197, 2016.

Maseyk, K., Berry, J. A., Billesbach, D., Campbell, J. E., Torn, M. S., Zahniser, M., and Seibt, U.: Sources and sinks of carbonyl sulfide in an agricultural field in the Southern Great Plains, P. Natl. Acad. Sci. USA, 111, 9064-9069, 2014.

Ogée, J., Sauze, J., Kesselmeier, J., Genty, B., Van Diest, H., Launois, T., and Wingate, L.: A new mechanistic framework to predict OCS fluxes from soils, Biogeosciences, 13, 2221-2240, https://doi.org/10.5194/bg-13-2221-2016, 2016.

Penman, H. L.: Gas and Vapor Movements in the Soli: I. The diffusion of vapors through porous solids, J. Agric. Sci., 30, 437-462, 1940.

Piazzetta, P., Marino, T., and Russo, N.: The working mechanism of the beta-carbonic anhydrase degrading carbonyl sulphide (COSase): a theoretical study, Phys. Chem. Chem. Phys., 17, 14843-14848, 2015.

Sánchez-Cañete, E. P., Scott, R. L., Van Haren, J., and BarronGafford, G. A.: Improving the accuracy of the gradient method for determining soil carbon dioxide efflux, J. Geophys. Res.Biogeosci., 122, 50-64, https://doi.org/10.1002/2016JG003530, 2017.

Seibt, U., Kesselmeier, J., Sandoval-Soto, L., Kuhn, U., and Berry, J. A.: A kinetic analysis of leaf uptake of COS and its relation to transpiration, photosynthesis and carbon isotope fractionation, Biogeosciences, 7, 333-341, https://doi.org/10.5194/bg-7333-2010, 2010.

Seibt, U., Wingate, L., Lloyd, J., and Berry, J. A.: Diurnally variable $\delta^{18} \mathrm{O}$ signatures of soil $\mathrm{CO}_{2}$ fluxes indicate carbonic anhydrase activity in a forest soil, J. Geophys. Res.-Atmos., 111, G04005, https://doi.org/10.1029/2006JG000177, 2006.

Singer, A.: The soils of Israel, Springer Science \& Business Media, p. 306, 2007.

Smith, N. A. and Kelly, D. P.: Oxidation of carbon disulphide as the sole source of energy for the autotrophic growth of Thiobacillus thioparus strain TK-m, Microbiology, 134, 3041-3048, 1988.

Steinbacher, M., Bingemer, H. G., and Schmidt, U.: Measurements of the exchange of carbonyl sulfide (OCS) and carbon disulfide 
$\left(\mathrm{CS}_{2}\right)$ between soil and atmosphere in a spruce forest in central Germany, Atmos. Environ., 38, 6043-6052, 2004.

Sun, W., Maseyk, K., Lett, C., and Seibt, U.: A soil diffusionreaction model for surface COS flux: COSSM v1, Geosci. Model. Dev., 8, 3055-3070, 2015.

Sun, W., Kooijmans, L. M. J., Maseyk, K., Chen, H., Mammarella, I., Vesala, T., Levula, J., Keskinen, H., and Seibt, U.: Soil fluxes of carbonyl sulfide (COS), carbon monoxide, and carbon dioxide in a boreal forest in southern Finland, Atmos. Chem. Phys., 18, 1363-1378, https://doi.org/10.5194/acp-18-1363-2018, 2018.

Svoronos, P. D. and Bruno, T. J.: Carbonyl sulfide: a review of its chemistry and properties, Ind. Eng. Chem. Res., 41, 5321-5336, 2002.

Van Diest, H. and Kesselmeier, J.: Soil atmosphere exchange of carbonyl sulfide (COS) regulated by diffusivity depending on water-filled pore space, Biogeosciences, 5, 475-483, https://doi.org/10.5194/bg-5-475-2008, 2008.

Viktor, A. and Cramer, M. D.: The influence of root assimilated inorganic carbon on nitrogen acquisition/assimilation and carbon partitioning, New Phytol., 165, 157-169, 2005.

Wehr, R., Commane, R., Munger, J. W., McManus, J. B., Nelson, D. D., Zahniser, M. S., Saleska, S. R., and Wofsy, S. C.: Dynamics of canopy stomatal conductance, transpiration, and evaporation in a temperate deciduous forest, validated by carbonyl sulfide uptake, Biogeosciences, 14, 389-401, https://doi.org/10.5194/bg14-389-2017, 2017.

Whelan, M. E. and Rhew, R. C.: Carbonyl sulfide produced by abiotic thermal and photodegradation of soil organic matter from wheat field substrate, J. Geophys. Res.-Biogeosci., 120, 54-62, 2015.

Whelan, M. E., Min, D.-H., and Rhew, R. C.: Salt marsh vegetation as a carbonyl sulfide (COS) source to the atmosphere, Atmos. Environ., 73, 131-137, 2013.
Whelan, M. E., Hilton, T. W., Berry, J. A., Berkelhammer, M., Desai, A. R., and Campbell, J. E.: Carbonyl sulfide exchange in soils for better estimates of ecosystem carbon uptake, Atmos. Chem. Phys., 16, 3711-3726, https://doi.org/10.5194/acp16-3711-2016, 2016.

Whelan, M. E., Lennartz, S. T., Gimeno, T. E., Wehr, R., Wohlfahrt, G., Wang, Y., Kooijmans, L. M. J., Hilton, T. W., Belviso, S., Peylin, P., Commane, R., Sun, W., Chen, H., Kuai, L., Mammarella, I., Maseyk, K., Berkelhammer, M., Li, K. F., Yakir, D., Zumkehr, A., Katayama, Y., Ogée, J., Spielmann, F. M., Kitz, F., Rastogi, B., Kesselmeier, J., Marshall, J., Erkkilä, K. M., Wingate, L., Meredith, L. K., He, W., Bunk, R., Launois, T., Vesala, T., Schmidt, J. A., Fichot, C. G., Seibt, U., Saleska, S., Saltzman, E. S., Montzka, S. A., Berry, J. A., and Campbell, J. E.: Reviews and syntheses: Carbonyl sulfide as a multi-scale tracer for carbon and water cycles, Biogeosciences, 15, 36253657, https://doi.org/10.5194/bg-15-3625-2018, 2018.

White, M. L., Zhou, Y., Russo, R. S., Mao, H., Talbot, R., Varner, R. K., and Sive, B. C.: Carbonyl sulfide exchange in a temperate loblolly pine forest grown under ambient and elevated $\mathrm{CO}_{2}$, Atmos. Chem. Phys., 10, 547-561, https://doi.org/10.5194/acp10-547-2010, 2010.

Yang, F., Qubaja, R., Tatarinov, F., Rotenberg, E., and Yakir, D.: Assessing canopy performance using carbonyl sulfide measurements, Glob. Change Biol., 24, 3486-3498, 2018.

Yi, Z., Wang, X., Sheng, G., Zhang, D., Zhou, G., and Fu, J.: Soil uptake of carbonyl sulfide in subtropical forests with different successional stages in south China, J. Geophys. Res.-Atmos., 112, D08302, https://doi.org/10.1029/2006JD008048, 2007. 